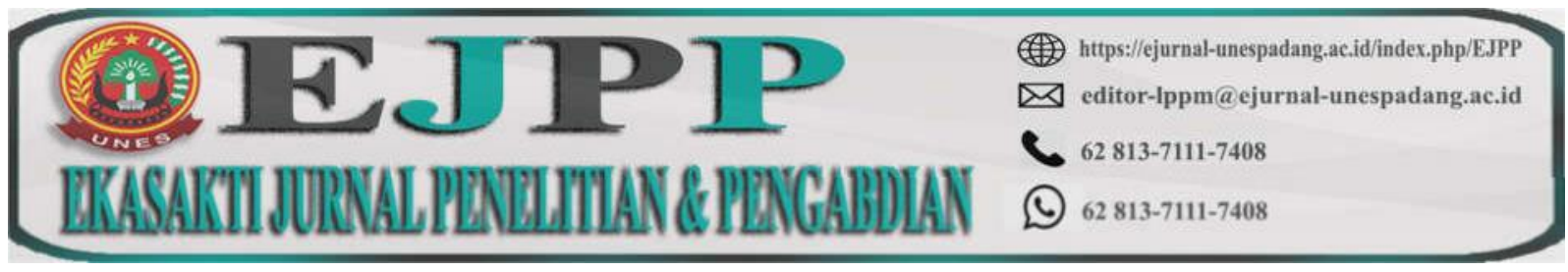

DOI: https://doi.org/10.31933/ejpp.v1i1

Received: 03/11/2020, Revised: 18/11/2020, Publish: 22/11/202

\title{
PKM PENGELOLAAN USAHA PEDAGANG KAKI LIMA DI PASAR TABING KOTA PADANG
}

Ariusni dan Syamsul Amar B ${ }^{2}$

1) Universitas Negeri Padang

Email: ariusni.fe.unp@gmail.com

2) Universitas Negeri Padang

\begin{abstract}
ABSTRAK
Tujuan kegiatan penerapan Program Kemitraan Masyarakat pada kelompok mitra pedagang kaki lima pasar Tabing Kota Padang adalah meningkatkan pengetauhuan pengelolaan keuangan dalam usaha dan rumah tangga pedagang kaki lima, manajemen usaha, akses kepada perbankan serta lembaga keuangan lainnya. Metode pendekatan yang ditawarkan untuk menyelesaikan persoalan mitra adalah a) pelatihan yang relevan pedagang kaki lima yang berkenaan dengan pengelolaan usaha agar usaha mereka maju dan berkembang, b) manajemen usaha agar bisa menjalankan usahanya secara professional dan menghasilkan pendapatan yang meningkat, c) akses ke perbankan serta lembaga keuangan lainnya agar bisa mendapatkan modal tambahan sehingga usaha pedagang kaki lima semakin berkembang. Hasil pengabdian ditemukan bahwa (1). pentingnya diberikan pengetahuan yang berhubungan dengan tambahan pengetahuan tentang Pengelolaan Usaha Pedagang Kaki Lima tentang Manajemen usaha mikro kecil menengah (UKMN) agar usaha yang dikelolanya sukses dan berkembang sehingga meningkatkan pendapatan pedagang kaki lima Pasar Tabing Kota Padang. (2). Dengan pelatihan ini peserta baru memahami bagaimana Pengelolaan keuangan usaha dan rumah tangga dan membuat catatan keuangan yang jelas sehingga pembukuan keuangannya tercatat dengan jelas dan (3). Peserta baru mengetahui cara mudah Akses kepada lembaga perbankan atau lembaga keuangan lainnya yaitu lembaga-lembaga yang menyediakan pinjaman bagi para UMKM.
\end{abstract}

Kata Kunci : Sektor informal, Pedagang kaki lima, Pengelolaan usaha.

\section{ABSTRACT}

The objective of the implementation of the Community Partnership Program in the street vendor partner group of the Tabing market in Padang City is to improve financial management knowledge in street vendors' businesses and households, business management, access to banks and other financial institutions. The approach method offered 
to solve partner problems is a) relevant training for street vendors related to business management so that their business can progress and develop, b) business management so that they can run their business professionally and generate increased income, c) access to banking as well as other financial institutions so that they can get additional capital so that the street vendor business grows. The results of the service found that (1). the importance of providing knowledge related to additional knowledge about the Management of Street Vendors Business on Management of Micro, Small and Medium Enterprises (UKMN) so that the businesses they manage are successful and develop so as to increase the income of street vendors in Pasar Tabing, Padang City. (2). With this training, new participants understand how to manage business and household finances and make clear financial records so that their financial books are recorded clearly and (3). New participants know how to easily access banking institutions or other financial institutions, namely institutions that provide loans to MSMEs.

\section{Keywords: Informal Sector, Street Vendors, Business Management}

\section{PENDAHULUAN}

Kawasan perkotaan merupakan tempat yang subur bagi munculanya sektor informal (Hayami, 2010). Kondisi ini dikarenakan banyaknya peluang dan potensi ekonomi diperkotaan terutama kota-kota besar dan ibu kota propinsi. Akibatnya pemerintah kota harus berhadapan dengan berbagai macam persoalan yang terus meningkat, kompleks dan menumpuk sementara kemampuan dan sumberdaya yang dimilikinya relatif terbatas. Dengan terbatasnya daya serap tenaga kerja maupun daya tampung kota mengakibatkan angka penggangguran cenderung mengalami peningkatan. Di sisi lain peningkatan pengangguran dari waktu ke waktu adalah refleksi dari rendahnyanya kualifikasi tenaga kerja untuk dapat memasuki sektor formal.

Fenomena ini dipertegas oleh Dinas Tenaga Kerja dan Transmigrasi Kota Padang (2019) yang menyatakan perbandingan antara pencari kerja, kesempatan kerja serta kualifikasi yang memenuhi syarat masih sangat timpang. Dari 10 orang pencari kerja hanya tersedia 2 kesempatan kerja dan dari 2 kesempatan kerja tersebut hanya bisa ditempati oleh 1 orang yang memenuhi kualifikasi. Dengan kata lain perbandingan antara pencari kerja dengan kesempatan kerja serta kualifikasi yang memenuhi yakni $10: 2: 1$.

Sulit dan ketatnya kesempatan kerja pada sektor formal menyebabkan sektor informal menjadi alternatif bagi tenaga kerja yang berkualifikasi rendah (Setturahman, 2015). Di sisi lain sektor informal juga memberikan kontribusi yang signifikan dalam memberikan pelayanan kepada masyarakat menengah ke bawah yang tidak terjangkau oleh sektor formal. Sektor informal menyediakan angkatan kerja perkotaan yang berada diluar pasar tenaga kerja yang teroganisir sebagai unit-unit yang berskala kecil baik itu dalam produksi maupun distribusi barang. Di sisi lain sektor informal ini tidak membutuhkan modal yang sangat besar sehingga semua orang bisa memasukinya. Sektor ini secara hukum tidak mempunyai legalitas, produkstivitas rendah, keahlian rendah dan tidak memerlukan pendidikan yang tinggi. Akan 
tetapi sektor ini sering ditentang oleh orang-orang diperkotaan dan juga lembaga pemerintah karena sering menimbulkan banyak permasalahan seperti sampah, kemacetan, kesembrautan dan fenomena sosial perkotaan lainnya (Subri, 2003).

Salah satu bentuk sektor informal di perkotaan adalah pedagang kaki lima. Pedagang kaki lima merupakan kelompok usaha yang tak terpisahkan dari aset pembangunan nasional yang berbasis kerakyatan. Pedagang kaki lima juga bagian integral dunia usaha nasional yang mempunyai potensi, kedudukan dan peranan yang sangat strategis untuk turut serta mewujudkan tujuan pembangunan nasional pada umumnya dan tujuan pembangunan ekonomi daerah khususnya. Potensi besar pada sektor informal seperti pedagang kaki lima mampu menciptakan dan memperluas lapangan kerja, terutama bagi tenaga kerja yang kurang memiliki kemampuan dan keahlian yang memadai untuk bekerja di sektor formal karena rendahnya tingkat pendidikan dan keahlian yang mereka miliki.

Dalam UU. No. 9 Tahun 1995 tentang Usaha Kecil, bahwa Usaha kecil termasuk pedagang kaki lima merupakan kegiatan usaha yang mampu memperluas lapangan kerja dan memberikan pelayanan ekonomi yang luas kepada masyarakat, berperan dalam proses pemerataan pendapatan masyarakat serta mendorong pertumbuhan ekonomi dalam mewujudkan stabilitas ekonomi nasional. Bahkan pedagang kaki lima, secara nyata mampu memberikan pelayanan terhadap kebutuhan masyarakat yang berpenghasilan rendah, sehingga tercipta suatu kondisi pemerataan hasil-hasil pembangunan. Selain itu, kelompok pedagang kaki lima mempunyai potensi yang cukup besar untuk memberikan kontribusi terhadap penerimaan Pendapatan Asli Daerah (PAD) di sektor penerimaan retribusi daerah seiring dengan kebutuhan daerah dalam rangka penyelenggaraan otonomi daerah.

Pedagang kaki lima ini umumnya berada pada sebuah pasar di tengah-tengah kehidupan perkotaan. Salah satu pasar yang ada di Kota Padang adalah Pasar Tabing. Pasar Tabing merupakan salah satu pasar yang cukup besar di Kota Padang dalam aktivitas ekonomi daerah di Kelurahan Parupuk Tabing. Aktivitas pedagang kaki lima di Pasar Tabing umumnya bergerak di sektor pangan seperti makanan ringan, buah-buahan, cabe, bumbu-bumbu masak, makanan siap saji dan lain-lain. Jenis pedagang ini jumlahnya lebih banyak dibanding kelompok pedagang kaki lima yang bergerak di sektor sandang dan barang-barang kelontong.

Banyaknya usaha pedagang kaki lima yang bergerak dibidang pangan seperti sayursayuran, buah-buahan, kentang, bumbu masakan, cabe dan lain-lain yang membuat pasar ini ramai dikunjungi oleh kaum ibu-ibu. Sebab jenis dagangan ini adalah kebutuhan pokok bagi sebuah keluarga. Oleh sebab itu permintaan akan pangan sebagai kebutuhan sehari-sehari sangat tinggi. Inilah penyebab bahwa bidang pangan merupakan bidang yang potensial bagi pedagang kaki lima.

Berdasarkan hasil pengamatan di lapangan terlihat bahwa masih banyak pedagang kaki lima di pasar ini yang memperoleh pendapatan rata-rata per bulan masih tergolong rendah. Indikasi rendahnya tingkat pendapatan mereka dapat ditelusuri melalui kepemilikan rumah tinggal. Sebagian besar pedagang kaki lima ini masih mengontrak rumah, bahkan ada di antara 
mereka yang masih tinggal di rumah keluarga. Disamping itu kemampuannya dalam memenuhi kebutuhan pokok keluarga seperti membiayai pendidikan anak-anaknya dan tingkat kesehatan juga masih rendah (Survey, 2020).

Rendahnya kehidupan pedagang kaki lima di Pasar Tabing ini diduga oleh rendahnya pembinaan terhadap pedagang-pedagang tersebut. Setelah dilakukan wawancara dengan beberapa pedagang kaki lima hampir $90 \%$ menyatakan bahwa mereka belum pernah mendapatkan pembinaan dari pemerintah setempat. Masalah pembinaan ini berkaitan dengan faktor-faktor yang berkaitan dengan masalah pemberdayaan sektor informal, khususnya pengelolaan pedagang kaki lima, yakni masalah pengelolaan keuangan, manajemen usaha, serta akses modal kepada perbankan dan lembaga keuangan lainnya.

Dari hasil survey dan wawancara dengan beberapa pedagang kaki lima tersebut dapat diidentifikasi persoalan-persoalan yang dihadapi oleh pedagang kaki lima (mitra) untuk diselesaikan agar usaha mereka menjadi lebih berkembang. Persoalan-persoalan tersebut diantaranya adalah:

1. Pedagang kaki lima belum punya pengetahuan dalam pengelolaan keuangan baik modal maupun keuangan rumah tangganya;

2. Pada umunya pedagang kaki lima belum mengerti dalam pengelolaan usaha (manajemen usaha) sehingga tidak mengerti bagaimana merencanakan, menorganisasikan, mengelola secara efektif dan efisien usaha mereka;

3. Lebih dari $50 \%$ pedagang kaki lima belum tersentuh oleh lembaga pemberdayaan pemerintaah;

4. Keahlian pedagang kaki lima masih sangat rendah sehingga produktivitas yang dihasilkannya juga rendah;

5. Pedagang kaki lima pada umumnya masih sulit terorganisir karena mereka gampang masuk pasar dan keluar dari pasar;

6. Pedagang kaki lima masih sangat sulit akses pada lembaga keuangan dan lembaga lainnya dalam meningkat permodalannya;

7. Pendapatan pedagang kaki lima masih sangat rendah sehingga masih sulit untk memenuhi kebutuhan pokoknya seperti memiliki rumah dan menyekolahkan anaknya pada jenjang yang lebih tinggi;

8. Dengan pendapatan yang rendah itu, mereka belum bisa mengelola dengan baik untuk memenuhi kebutuhan rumah tangganya;

9. Pedagang kaki lima juga bersaing dengan pedagang-pedagang lainnya.

Apabila pedagang kaki lima ini dibina dengan baik maka usaha dari pedagang kaki lima ini akan diperkirakan semakin bertambah maju. Karena potensi pedagang kaki lima untuk mengembangkan usahanya di Pasar Tabing ini sangat tinggi. Hal ini terlihat dari banyaknya rumah tangga yang berada di sekitar kawasan pasar ini. Seperti data yang dapat dilihat pada Tabel 1 bahwa daerah disekitar Pasar Tabing ini yaitu Kelurahan Parupuk Tabing mempunyai jumlah rumah tangga sebanyak 5.085 unit. Begitu besar potensi jumlah permintaan rumah tangga 
untuk bertransaksi di Pasar Tabing. Belum lagi kelurahan-kelurahan yang ada di sekitar Kelurahan Parupuk Tabing seperti Kelurahan Lubuk Minturun Sungai Lareh, Kelurahan Bungo Pasang, dan Kelurahan Batang Kabung Ganting. Potensi permintaan transaksi jual-beli menjadi bertambah besar karena sebagian masyarakat dari kelurahan-kelurahan tersebut melintasi daerah ini. Dengan demikian mereka akan singgah untuk melakukan jual-beli.

Tabel 1. Jumlah Rumah Tangga, Penduduk, dan Kepadatan Menurut Kelurahan di Kecamatan Koto Tangah Tahun 2019

\begin{tabular}{lccc}
\hline \multicolumn{1}{c}{ Kelurahan } & $\begin{array}{c}\text { Rumah Tangga } \\
\text { (Unit) }\end{array}$ & $\begin{array}{c}\text { Penduduk } \\
\text { (Jiwa) }\end{array}$ & Kepadatan \\
\hline Dadok Tunggul Hitam & 4.724 & 18.898 & 1.547 \\
Air pacah & 2.586 & 10.346 & 676 \\
Lubuk Minturun Sungai Lareh & 2.244 & 8.976 & 378 \\
Bungo Pasang & 3.113 & 12.453 & 3.711 \\
Parupuk Tabing & 5.085 & 20.341 & 2.160 \\
Batang Kabung Ganting & 3.360 & 13.438 & 3.968 \\
Lubuk Buaya & 5.754 & 23.015 & 6.106 \\
Padang Sarai & 5.004 & 20.014 & 1.457 \\
Koto Panjang Ikua Koto & 3.084 & 12.336 & 1.454 \\
Pasir Nan Tigo & 2.359 & 9.435 & 647 \\
Koto Pulai & 610 & 2.438 & 438 \\
Balai Gadang & 4.006 & 16.023 & 145 \\
Batipuh Panjang & 3.646 & 14.583 & 990 \\
\hline Sul Keca
\end{tabular}

Sumber: Kecamatan Koto Tangah Dalam Angka (2019)

Berdasarkan hasil diskusi dengan pedagang kaki lima dari hasil observasi langsung ke lokasi Pasar Tabing maka ada beberapa permasalahan pedagang kaki lima yang mendesak untuk di atasi:

a. Pengelolaan keuangan

Rendahnya pengetahuan pedagang kaki lima dalam pengelolaan keuangan dalam usaha dan keuangan dalam rumah tangga sehingga masih sulit bagi mereka untuk menabung dan menambah modal usaha yang diperoleh dari keuntungan berjualan. Hal ini disebabkan pada umumnya para pedagang kaki lima ini tidak mempunyai tingkat pendidikan yang tinggi.

b. Manajemen usaha

Pedagang kaki lima tidak mempunyai pengetahuan dalam pengelolaan usaha yang efektif dan efisien. Manajemen usaha sangat dibutuhkan agar usaha bisa berkembang dan berjalan dengan baik dan maju. Diantara manajemen usaha ini adalah manajemen keuangan, manajemen penjualan, manajemen produksi, manajemen distribusi, dan manajemen sumberdaya manusia.

c. Akses kepada perbankan dan lembaga keuangan lainnya

Pada umumnya pedagang kaki lima hampir tidak pernah mengenal bank sebagai salah satu sumber pinjaman dalam hal permodalan. Khusus Kredit Usaha Rakyat (KUR) 
masih sangat sulit diperoleh oleh usaha kecil seperti pedagang kaki lima. Akan tetapi kebanyakan usaha menengah keatas sangat gampang akses terhadap KUR. Setiap kali usaha kecil mengkases KUR, bank selalu memberatkan dari segi anggunan, padahal pemerintah memberikan subsidi yang sangat besar untuk KUR. Tetapi masalah dilapangan sering disalahgunakan untuk kepentingan pribadi oleh para penyalur KUR. Pada dasarnya pedagang kaki lima juga berhak mendapatkan KUR. Akan tetapi sangat sulit akses pada KUR tersebut. Salah satu syarat yang diminta oleh bank penyalur KUR adalah pedagang kaki lima harus punya surat izin usaha. Ini suatu masalah berat bagi pedagang kaki lima untuk memenuhi syarat itu meskipun mereka punya usaha. Jenis KUR yang berhak diterima oleh pedagang kaki lima adalah KUR mikro dengan plafon sampai Rp.25 juta rupiah. Syarat lain dari KUR mikro itu harus memiliki usaha produktif dan layak, telah melakukan usaha secara aktif minimal enam bulan serta tidak sedang menerima kredit perbankan kecuali kredit konsumtif. Untuk hal ini pedagang kaki lima di Pasar Tabing banyak yang tidak tahu akan jenis kredit ini disedikan oleh pemerintah. Meskipun mereka tahu, akan tetapi sangat sulit akses untuk mendapatkan KUR mikro ini.

\section{METODE PENELITIAN}

Metode pendekatan yang diterapkan untuk menyelesaikan persoalan pedagang kaki lima adalah pelatihan dan pendampingan. Pelatihan dan pendampingan ini bertujuan untuk meningkatkan pengetahuan dan keterampilan mitra dalam bidang:

1. pengelolaan keuangan baik dalam usaha maupun dalam rumah tangga;

2. manajemen usaha agar efektif dan efisien;

3. kemampuan akses pada lembaga perbankan atau lembaga keuangan lainnya.

Pelatihan akan dilakukan oleh para instruktur yang sudah berpengalaman dalam bidang pemberdayaan ekonomi masyarakat seperti akedemisi dari perguruan tinggi, praktisi manajemen usaha, serta praktisi perbankan. Metode yang digunakan dalam pelatihan diantaranya ceramah, diskusi, tanya jawab, praktek pengelolaan keuangan, manajemen usaha dan akses kepada perbankan. Kemudian pendampingan untuk memastikan apakah materi dapat diaplikasikan dalam kegiatan usaha sehari-hari.

Tahapan pelaksanaan kegiatan pelatihan terdiri dari:

a. Persiapan: Pertemuan dengan perwakilan mitra dan ketua pengelola Pasar Tabing untuk menyepakati jadwal dan lokasi pelaksanaan kegiatan.

b. Persiapan materi pelatihan oleh para instruktur

c. Pelaksanaan kegiatan pelatihan (September - Oktober 2020)

d. Monitoring terhadap hasil pelatihan yang telah dilakukan. Kerangka pemecahan masalah dalam kegiatan ini dapat dilihat pada Gambar 1 berikut: 


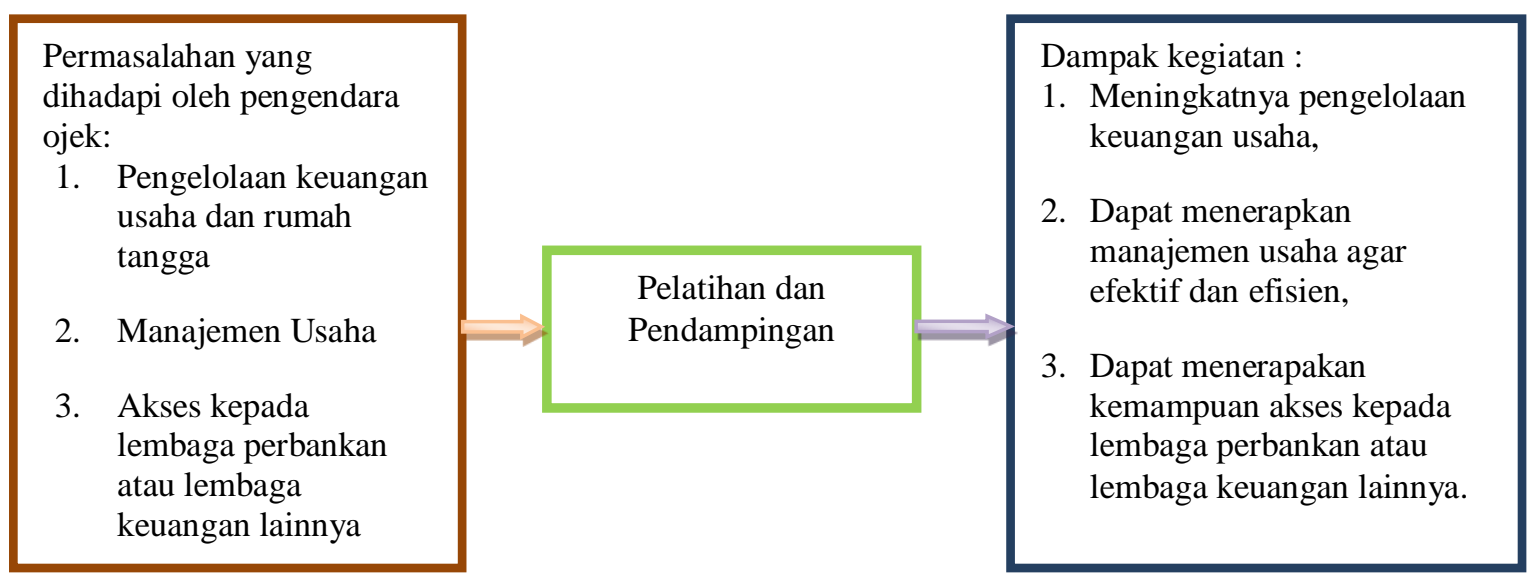

Gambar 1 : Kerangka Pemecahan Masalah

\section{HASIL DAN PEMBAHASAN}

Hasil yang dicapai dalam kegiatan Program Kemitraan Masyarakat (PKM) Pengelolaan Usaha Pedagang Kaki Lima di Pasar Tabing Kota Padang adalah:

1. Kehadiran dalam Kegiatan Pelatihan Pengelolaan Usaha Pedagang Kaki Lima di Pasar Tabing Kota Padang;

2. Peserta dalam kegiatan PKM Pengelolaan Usaha Pedagang Kaki Lima di Pasar Tabing Kota Padang berjumlah 21 orang. Kehadiran peserta dalam mengikuti pelatihan dapat dilihat dalam daftar hadir peserta;

3. Motivasi mengikuti kegiatan; Motivasi peserta dalam mengikuti kegiatan PKM adalah tinggi, dimana peserta hadir diundang 20, orang akan tetapi yang datang lebih dari itu serta mereka datang tepat waktu baik pada saat acara pelatihan dimulai, untuk mengikuti acara pelatihan yang dilakukan oleh para instruktur.

Materi yang disajikan meliputi Peningkatan pengetahuan tentang Pengelolaan Usaha Pedagang Kaki Lima. Pada kegiatan PKM Pengelolaan Usaha Pedagang Kaki Lima di Pasar Tabing Kota Padang topik yang disampaikan yaitu: Manajemen usaha mikro kecil menengah (UKMN). Materi yang disajikan meliputi; menjelaskan ciri-ciri UKMN yaitu Jenis komoditi/ barang yang ada pada usahanya tidak tetap, atau bisa berganti sewaktu-waktu; Tempat menjalankan usahanya bisa berpindah sewaktu-waktu; Usahanya belum menerapkan administrasi, bahkan keuangan pribadi dan keuangan usaha masih disatukan; Sumber daya manusia (SDM) di dalamnya belum punya jiwa wirausaha yang mumpuni; Biasanya tingkat pendidikan SDM nya masih rendah; Biasanya pelaku UMKM belum memiliki akses perbankan, namun sebagian telah memiliki akses ke lembaga keuangan non bank; Pada umumnya belum punya surat ijin usaha atau legalitas, termasuk NPWP. Kemudian menjelaskan konsep UKMN yaitu UMKM adalah kelompok usaha kecil yang produktif dan memiliki peran penting dalam perekonomian di Indonesia; Begitu pentingnya peranan UMKM di Indonesia, bahkan disebutsebut sebagai tulang punggung perekonomian Indonesia. Itulah sebabnya kerjasama untuk 
pengembangan dan ketahanan UMKM sangat perlu diutamakan. Materi selanjutnya menjelaskan pentingnya manajemen bagi UKMN seperti pedagang kaki lima Di Kota Padang mengelola usajhanya agar sukses dan berkembang sehingga meningkatkan pendapatan pedagan kaki lima Pasar Tabing Kota Padang.

Seringkali Permasalahan utama yang dihadapi oleh pelaku UKM antara lain dari sisi manajemen usaha. Manajemen yang diartikan mencapai sasaran bersama dan melalui orang lain, oleh pengusaha kecil umumnya kurang diterapkan karena semua hal dikerjakan sendiri. Dari seluruh aspek manajemen mulai proses pemasaran, produksi, SDM sampai keuangan. Oleh Karena itulah sebaiknya untuk bisa berkembang pelaku usaha kecil harus mulai bisa mendelegasikan sebagian aspek manajemen usahanya ke pihak lain sehingga mereka bisa memikirkan ke arah pengembangan usaha. Fungsi manaejemn datu pengelolan juga sangat penting antara lain perencanaan, pengelolaa, pengawasan dan pelaksanaan. Dalam manajemen pemasaran membahsa tentang empat aspek yaitu Strategi harga; Strategi tempat; Strategi produk; Strategi promosi. Selanjutnya pemateri ini membahas tentang Aspek-aspek penting untuk manajemen ukm: Pemasaran, Produksi, Sumber daya manusia dan Keuangan. Manajemen produksi: proses produksi, lay out, sistem mutu, pruduktivitas dan efisiensi. Manajemen Keuangan: Sumber modal, amanjemen kas, anggaran dan laporan keuangan. Penyampain topik ini sangat bermanfaat bagi peserta pelatihan pedagangan kaki lima pasar Tabing dengan menambah pengetahuan mereka sehingga bisa diterpakan dalam usahanya. Setelah penyampaian materi narasumber memberikan kesempatan kepada para peserta untuk bertanya, atau mendiskusikan berbagai persoalan yang berhubungan dengan manajemen usaha mikro kecil menengah (UKMN). Hasil yang dicapai adalah peningkatan pengetahuan para peserta kegiatan PKM mengelola usaha dan mengembangkan usaha mereka menjadi lebih baik sehingga bisa meningkatkan pendapatan dan kesejahteraan mereka.

Materi berikutnya berkaitan dengan Pengelolaan keuangan usaha dan rumah tangga. Materi yang disajikan meliputi; Praktek pembukuan laba-rugi bagi pelaku usaha dengan penerapan akuntansi sederhana. Narasumber menjelaskan konsep laporan laba-rugi yaitu laporan keunagan yang menyajikan ringkasan dari pendapatan dan biaya untuk sustu periode tertentu, misalnya satu bulan, satu tahun berdasarkan konsep yang disebut juga konsep pengaitan atau pemadanan anatar pendapatan dan beben yang terkait, konsep ini diterapkan denagn memadanan baiaya dan pendapatan yang dihasilkan dalam periode terjadinya beban tersebut. Jika pendapatan lebih besar daripada biaya disebut laba, dan sebaliknya jika bebena menlebihi pendapatan disebut rugi; fungsi laporan laba rugi adalah menunjukan perfomance atau kinerja keuangan perusahaan atau usaha. Dengan melakukan analisis terhadap laba rugi, pengelola bisnis dalam hal ini manajemen perusahaan dapat memutuskan strategi yang tepat untuk dilakuakn pada periode berikutnya; format laporan laba rugi,serta contoh soal laporan laba rugi. Penyampaian topik sangat diperlukan sekali disebabkan masalah yang selalu dihadapi oleh calon wirausaha baru pengembangan kualitas produk agroindustri pengolahan ikan laut pada siswa SMKN 3 Kota Pariaman adalah dalam bidang pemasaran. Hasil yang dicapai adalah 
peningkatan pengetahuan dalam membuat laporan keuangan masing-masing usaha yang dilakukan oleh para pedagang sebagai peserta kegiatan PKM Pengelolaan Usaha Pedagang Kaki Lima di Pasar Tabing Kota Padang sehingga dapat mengelola keuangannyanya dengan jelas apakah untuk atau rugi yang selama ini belum pernah dilakukan oleh para pedagang tersebut. ini membaut usaha mereka semakin mudah berkembang dan jelas pengelolaan keuangan mereka.

Materi yang sangat penting bagi pedagangan kakilima dalah bagaiman Akses kepada lembaga perbankan atau lembaga keuangan lainnya. Materi ini meliputi: menjelaskan lembagalembaga yang menyediakan pinjaman bagi para UMKM, menjelasakan lembaga keuangan satu persatu sperti Koperasi Syariah, apa landasan koperasi syariah dengan dasar sistem ekonomi syariah, tujuan sistem ekonomi syariah, kaidah usul fiqih yang dipakai, karakteristik koperasi syariah, bagaimana penghimpunan dananya, penyaluran dana, jensi-jenis produk simpanannya seperti Sijari, Sikeris, dan lain lain-lain, produk pembiayaannnya (memiliki unsur kepercayaan waktu, resiko, penyerahan dan akad), mamnfaat pembiayaan, skema akad pembiayaan (Syirkah, Bai', sewa, dan fee), skema pembaiyaan mudaharabah, rukun jual beli, syarat harga, skema Wakalah dan syarat-syaratnya dan akad, pinjaman Qordhul Hasan, karakteristik akan pembiayaan, badan hukum lembaga pembiayaan, manajemen dan karyawan koperasi syariah, stnadar akuntansi dan pelaporan Koperasi Syariah (fungsi koperasi Syariah dan tujunnya serta acuan penyusunan laporan keuangan,ketentuan umumnya, keterbatasan laporan keuangan, acuan umum dan acuan khusus). Topik ini adalah penting bagi Pedagang Kaki Lima di Pasar Tabing Kota Padang mengingat pedagang sangat membutuhkan modal tambahan usaha sementara mereka pada umumnya tidak tahu bagaimana cara menimjam pada lembaga keuangan terutama pada lembaga keuangan syariah seperti koperasi syariah yang telah diajarkan. Mereka mungkin ada juga terjerat pada pinjaman individu lintah darat. Dengan adanya materi ini terbuka wawasan para pedagang ini mudahnya meminjam kepada lembaga syariah apalagi sesuai dengan tuntunan agama yang jauh dari unsur riba. Hasil yang dicapai dengan penyampaian materi akses kepada lembaga perbankan atau lembaga keuangan lainnya ini adalah meningkatkan pengetahuan para peserta kegiatan PKM Pengelolaan Usaha Pedagang Kaki Lima di Pasar Tabing Kota Padang. Akses mereka pada lembaga keuangan sangat jelas dan mudah dalam meningkatkan penambahan modal usah mereka agar usaha mereka kedepannya semakin maju, berhasil dan berkembang sehingga pendapatan para pedaganga kaki lima Pasar Tabing ini meningkat. Peluang padagang kkai lima bisa banyak akses pada lembaga keuangan dan non keuangan lainnya. Mereka bisa memilih pembiayan keuangan yang mana yang akan dipilihnya kedepan dalam rangka membantu permodalan usahanya.

\section{KESIMPULAN DAN SARAN}

Berdasarkan permasalahan dan pembahasan dalam pengelolaan Usaha Pedagang Kaki Lima di Pasar Tabing Kota Padang pentingnya diberikan pengetahuan yang berhubungan dengan tambahan pengetahuan tentang Pengelolaan Usaha Pedagang Kaki Lima tentang Manajemen usaha mikro kecil menengah (UKMN) agar usaha yang dikelolanya sukses dan berkembang 
sehingga meningkatkan pendapatan pedagang kaki lima Pasar Tabing Kota Padang. Dengan pelatihan ini peserta baru memahami bagaimana Pengelolaan keuangan usaha dan rumah tangga dan membuat catatan keuangan yang jelas sehingga pembukuan keuangannya tercatat dengan jelas dan baru mengetahui cara mudah Akses kepada lembaga perbankan atau lembaga keuangan lainnya yaitu lembaga-lembaga yang menyediakan pinjaman bagi para UMKM.

\section{REFERENSI}

Badan Pusat Statistik Kota Padang. 2019. Kecamatan Koto Tangah Dalam Angka. Padang : Badan Pusat Statistik.

Hayami, Yojiro and Yohihisa Godo. 2010. Developmen Economics; From the Poverty to the Wealth of Nation. New York : Oxford University Press.

Dinas Tenaga Kerja dan Transmigrasi Kota Padang. 2019. Laporan Tahunan. Padang : Disnakertrans Kota Padang.

Seturrahman. 2015. Sektor Informal di Negara Sedang Berkembang. Jakarta : Gramedia Pustaka Umum.

Subri. 2003. Ekonomi Sektor Informal. Jakarta: PT Raja Grafindo Persada 